\title{
Heinrich Bullinger se leer oor verbond en uitverkiesing as antwoord op die TULIP-problematiek
}

\author{
Jacobus de Koning \\ Noordwes-Universiteit, Potchefstroom, Suid-Afrika \\ jdwkoning@gmail.com
}

\begin{abstract}
Heinrich Bullinger's doctrine on covenant and election in response to the problematic nature of TULIP
\end{abstract}

In this article, the question was raised whether a new appreciation and application of Heinrich Bullinger's doctrine of the covenant and of election could give rise to a more pastoral and non-rational way of thinking in relation to election/predestination as reflected in the five points of TULIP. Responses to TULIP within current evangelical theological circles were examined. Specifically Dave Hunt's book, 'What love is this' and the New Calvinism, were scrutinized in this regard, before it was indicated why Bullinger's view of the covenant and of election were chosen as the answer to the problem mentioned above. After investigating Bullinger's theology with regard to the covenant and election in contrast to later developments, it was shown how his view of the central place of the covenant in the history of revelation influences his doctrine of election to such an extent that his historical and Christological focus brings a more biblical version of election than that of TULIP to the evangelical discussion. Finally, some implications of his theology, especially for evangelical theology, are addressed.

Key words

Heinrich Bullinger; TULIP; Evangelicalism; New Calvinism; covenant; election; predestination

\section{Inleiding}

Jonker (1989:15) wys daarop dat daar van die begin van die kerk se geskiedenis besondere probleme verbonde was aan die leer van die uitverkiesing. Sodra die leer van verkiesing uit die doksologiese konteks 
van die Bybel gehaal word en rasioneel hanteer word, duik daar probleme vir die mens se logiese denke en morele besef op.

Genoemde problematiek is steeds aktueel, soos gesien in die reaksie binne evangeliese kringe op die sogenaamde vyf punte van Calvinisme, ook bekend as die "doctrines of grace" en beskryf met die akroniem TULIP (Total depravity, Unconditional election, Limited atonement, Irresistible grace, Perseverance of the saints). Hierdie vyf punte is verseker gepopulariseer deur die verskyning van Steele, Thomas en Lance se boekie, The five points of Calvinism: Defined, Defended, Documented in 1963. Populêre en gerespekteerde skrywers binne die evangeliese dampkring dui TULIP as die opsomming van die sinode van Dordrecht aan (Sproul:1997:27-28). Skrywers soos Muller (2012:50-51) en veral Stewart (2008:189) dui egter aan dat daar geen historiese verhouding tussen die akroniem TULIP en die sinode van Dordrecht bestaan nie. Hulle is ook van mening dat die taal van TULIP die betekenis van Dordrecht, Calvyn se teologie en die teologie van die 17de-eeuse ortodoksie skade berokken.

Oor die presiese plek en datum van ontstaan van die vyf punte en die akroniem is daar nie finale duidelikheid nie. ${ }^{1}$

Die vroegste verskyning van hierdie akroniem wat Stewart (2008:187-203) in sy navorsing in gedrukte formaat kon vind, was dié wat in Loraine Boettner se boek, The Reformed Doctrine of Predestination (1932) neergepen is. $^{2}$

Dit lê nie binne die omvang van hierdie artikel se verkenning om presies te probeer vasstel of TULIP die regmatige samevatting en verstaan van Calvyn is en of dit sinoniem met Calvinisme of Gereformeerde teologie is nie. Helm (1984:7-10) het reeds aangetoon dat daar totaal uiteenlopende standpunte rondom Calvyn en sy verhouding tot "Calvinisme" of "Gereformeerde teologie' bestaan. Daar is diegene wat met die verwysing na Calvyn aandui dat hy nie werklik verskil het van die teologie wat uiteindelik in die Westminster Confession of Faith neerslag vind nie, terwyl ander weer oortuigend kan aandui dat Calvyn teologies baie nader aan

1 Volgens Wail (1913:104) is die akroniem alreeds deur Cleland Boyd McAfee so vroeg as 1905 reeds gebruik.

2 Die boek is weer in 2015 deur GLH Uitgewers herdruk. 
Bart lê. Sommige teoloë soos byvoorbeeld Torrance (1994:19-33) onderskei ook tussen twee vorms van Calvinisme. Hy sien Federale Calvinisme of Westminster-teologie as die ontwikkelde vorm van Gereformeerde teologie wat sedert die sewentiende eeu en later wydverspreid voorkom en vanaf Bullinger tot by Ursinus en Olevianus nagespeur kan word. Volgens hom moet dit weer van Calvinisme, of hoë Calvinisme onderskei word, bedoelende die tradisie in die Calvyn-Beza-lyn van Genève.

Die feit is dat TULIP deur Christene binne evangeliese kringe verstaan word as Calvinisme of Gereformeerde teologie. In hierdie studie word aangetoon dat TULIP tot 'n teenreaksie van totale verwerping lei wat betref gereformeerdheid en God se soewereiniteit aan die een kant of'n halfhartige vashou aan TULIP, wat weer spanning bring met sekere formulerings van die saak binne Gereformeerde Belydenisskrifte.

Die vraag wat in hierdie studie op die tafel geplaas word, is dít: Kan 'n waardering en toepassing van die verbonds- en uitverkiesingsleer van Heinrich Bullinger nie dalk daartoe aanleiding gee dat daar in evangeliese kringe op 'n meer pastorale en nie-rasionele manier met die saak wat deur TULIP verwoord word, omgegaan sal word nie? Kan dit nie dalk veroorsaak dat daar wegbeweeg word van die logiese benadering van die onderwerp wat sodoende allerhande deterministiese voorstellings van die onderwerp in die kiem kan smoor en meer reg kan laat geskied aan die lofprysende karakter van die uitverkiesing, soos gevind in die Bybel nie? Kan 'n verstaan en waardering van Bullinger help om gereformeerdheid in 'n ander lig te stel?

Om hierdie vraag te beantwoord gaan daar eerstens op enkele gebeure ná die aanbreek van die millennium gefokus word, naamlik gebeure binne die evangeliese beskouing, waarin daar op 'n sekere manier op TULIP gereageer is.

Hierdie twee gebeure is a) die publikasie van Dave Hunt se boek, What love is this? en b) die ontwikkeling van die sogenaamde Nuwe Calvinisme (New Calvinism)

Nadat daar oorsigtelik gekyk is na evangeliese teologie en die twee genoemde gebeure, sal die vraag gevra word waarom juis Bullinger en sy teologie van uitverkiesing en verbond by uitstek geskik is om die 
problematiek rondom TULIP aan te spreek. Bullinger se verstaan van verbond en uitverkiesing en die wisselwerking daarvan in die omgaan van God met die mens in verkiesing en verlossing sal dan onder die loep kom, waarnaas die implikasies daarvan uitgelig sal word met die bedoeling om 'n moontlike oplossing te bied vir die problematiek wat deur TULIP in die evangeliese wêreld veroorsaak is.

\section{TULIP-problematiek in evangelies teologiese (evangelical) kringe}

\subsection{Wat is evangeliese teologie (evangelicalism)?}

Wat met die term evangeliese Christene en evangeliese teologie bedoel word, kan op sigself verwarring skep, aangesien dit nie altyd gemaklik onder een sambreel inpas nie. So byvoorbeeld gee Deist (1992: 88-89) alreeds vyf moontlike betekenisse van die term evangeliesgesindes (evangelicals). 'n Menskan inderwaarheid dievraagvra: Is daar werklik iets soos'n evangeliese teologie? Klaas Runia is van mening dat dit inderdaad nie moontlik is om van 'n eenvormige evangeliese teologie te praat nie aangesien mense van uiteenlopende denominasies, wat baie bewus is van hulle eie teologiese "wortels" en tradisie, tog hulleself as evangeliesgesindes (evangelicals) sal beskou. Hy verwys na Donald Bloesch wat gesê het dat die evangeliese teologie (evangelicalism) 'n stemming (mood) is eerder as 'n teologiese sisteem. Hy haal ook vir Carl Henry aan wat reken: "Evangelicalism is as much a temperament as a theology." (Runia 1997:292)

Tog is daar sekere oortuigings, waarhede en voorstellings wat by almal wat hulleself as "evangelicals" beskou, voorkom. Hierdie min of meer geïsoleerde waarhede en voorstellings vestig die platform waarvolgens evangeliesgesindes (evangelicals) mekaar ontmoet en uitken. By die eerste Evangeliese Bondgenootskap (Evangelical Alliance) in 1846 het die stigterslede nege sulke oortuigings daargestel ${ }^{3}$ wat volgens Runia (1997:294)

3 (1) Die Goddelike inspirasie, gesag en genoegsaamheid van die Heilige Skrif. (2) Die reg en plig van private oordeel in die interpretasie van die Skrif. (3) Die eenheid van God en die Drie-eenheid van persone in die Godheid.(4) Die totale verdorwenheid van menslike natuur as gevolg van die sondeval. (5) Die menswording (inkarnasie) van die Seun van God, Sy werk van versoening vir sondaars en sy bemiddelende intreding en regering. (6) Die regverdigmaking van sondaars deur geloof alleen. (7) Die werk van die Gees in die bekering en heiligmaking van die sondaar. (8) Die onsterflikheid 
deur feitlik al die Evangeliese Bondgenootskappe en baie ander Evangeliese Genootskappe gevolg is. Insiggewend is die feit dat daar naas die klem op die Goddelike inspirasie van die Skrif, klem gelê word op die reg en plig van private oordeel in die interpretasie van die Skrif. Die enigste oortuiging wat 'n raakpunt het met TULIP is aanvaarding van die totale verdorwenheid van die menslike natuur as gevolg van die sondeval. Sigbaar afwesig is die gedagte van beperkte versoening en selfs uitverkiesing; versoening word bloot genoem in verhouding tot sondaars.

König (1998:96) noem die kern hiervan as hy Evangeliese Teologie soos volg saamvat:

However, on the whole it is clear that a high view of the Bible, definite experience of conversion as a personal relationship with Christ and active involvement in witnessing to Christ will be included in all or at least most of the descriptions of the core of Evangelical Theology.

Natuurlik is hierdie sentrale sake nie na willekeur gekies nie. Daar is 'n teologiese verhouding tussen hulle, een wat afkomstig is van die feit dat die Evangeliese beweging sy eie "tradisie" het. Volgens Runia (1997:195-196) kan daar ten minste drie "lae" in die tradisie onderskei word. Die onderste "laag" is die 16de eeuse Reformasie. Die tweede 'laag' het verskillende name in verskillende lande maar daar is 'n definitiewe verwantskap tussen hulle. In Engelssprekende lande is daar die Puritanisme, vir die Duitssprekendes is dit Piëtisme en vir die Nederlanders die sogenaamde Nadere Reformasie.

Die derde "laag" is gevorm deur die verskillende Herlewingsbewegings in die 18de en 19de eeu. Hierdie bewegings vind hoofsaaklik in die Engelssprekende wêreld plaas, maar daar was ook soortgelyke bewegings in Duitsland en Nederland.

Benewens hierdie drie hooflae wat algemeen tot alle "evangelicals" deur die wêreld is, is daar ook volgens Runia (1997:295) twee ander bewegings wat hulle ontstaan in ons eeu gehad het en wat seker dele van die evangeliese

van die siel, die opstanding van die liggaam, die oordeel van die wêreld deur Jesus Christus, met die gevolg van ewige saligheid van die regverdige en ewige straf van die goddelose. (9) Die Goddelike instelling van die Christelike bediening en die verpligting en voortsetting van die instelling van die doop en nagmaal. 
teologie (evangelicalism) diep beïnvloed het. Hy noem fundamentalisme wat in die tydperk 1910-1930, in reaksie tot liberale teologie ontstaan het en dan in die tweede plek is daar die Pentekostalisme-beweging (Pinksterbeweging).

In die lig van die kenmerke van evangeliese teologie (evangelicalism), soos uitgelig, is dit heeltemal te begrype dat TULIP nie heeltemal inpas by alles wat hierdie beweging na aan die hart lê nie. Alhoewel die Reformasie wel een van die lae is waaruit die tradisie ontstaan het, het die herlewingsbeweging en Pentekostalisme (Pinksterbeweging) se klem op evangelisasie, bekering en die mens se rol en wil in bekering, sowel as heiligmaking, kan daar verwag word dat die gedagte van iets soos beperkte versoening nie hier goed ontvang sou word nie. As TULIP dus sinoniem is met Gereformeerd (Calvinisme), is dit te verwagte dat baie evangeliesgesindes (evangelicals) gemaklik daarmee sou wees om hulleself eerder as Arminiaans te beskou.

Dis presies wat gebeur het met die publikasie van Dave Hunt se boek, What love is this?

\subsection{Die publikasie van Dave Hunt se boek "What love is this?"}

Met hierdie eeuwending het ' $\mathrm{n}$ werk in fundamenteel-evangeliese kringe verskyn wat geen klein opskudding in dieselfde kringe veroorsaak het nie. Dit was What love is this? van Dave Hunt. In hierdie werk word 'n striemende aanval op Calvinisme, en meer spesifiek die uitverkiesingsleer. Voorstanders van Calvinisme - insluitend Calvyn - se werk word as lasterlik beskou (Hunt 2002:132) en hulle godsbeskouing word soos volg onder verdenking gebring: “ ... there is the distinct impression that we are talking about two different 'Gods' and two different 'gospels'. One is described in the Bible; the other is a product of Calvin's peculiar interpretation" (Hunt 2002: 153).

Dit lê nie binne die afbakening van ons verkenning om hier te wys op al die historiese, tegniese en teologiese probleme in verband met hierdie werk nie. Daar is heelparty sulke probleme. ${ }^{4}$ Die hooffokus van die boek is egter te vind in Hunt se hantering van die akroniem TULIP (Hunt

4 Selfs iemand soos Laurence M. Vance die outeur van The other side of Calvinism (Pensacola, FL: Vance Publications, 1991, 1999), wat self krities is teenoor Calvinisme, wys op allerlei probleme in hierdie boek in sy artikel "A review of Dave Hunts 'What 
2002:144-445). Daar kan natuurlik baie geredeneer word oor hierdie punte wat na die sinode van Dordrecht (1618-1619) teruggevoer kan word ${ }^{5}$. Volgens Jonker (1989:62-70) handel beide Calvyn en die Dordtse Leerreëls ${ }^{6}$ meer infralapsaries ${ }^{7}$ oor uitverkiesing en versoening as wat die geval by byvoorbeeld Beza en ander latere ontwikkelings was. Tog moet 'n mens ten spyte van al die verdraaiings Hunt se beswaar teen TULIP, wat hy op Calvyn projekteer en wat hy as Calvinisme beskryf, hoor, want dit is wat sekere evangeliese Christene waarskynlik hoor.

'n Tweeledige morele vraag kom uit Hunt se kritiek na vore: a) Is dit wat geleer word rondom God en sy verkiesing versoenbaar met die sterk klem wat die Bybel op die mens se verantwoordelikheid plaas? en b) Is dit in ooreenstemming met die goedheid van God? Kortom: Word die wese van God en die wese van die mens nie aangetas nie?

As Tim LaHaye, skrywer van populêre geestelike lektuur, se beoordeling van die boek enigsins 'n aanduiding is van die impak hiervan in ten minste sekere evangeliese kringe, kan dit nie ligtelik opgeneem word nie. Hy stel dit onomwonde:

love is this?" "Calvinism's misrepresentation of God", in Journal of the Grace Evangelical Society, Autumn 2002, 40-44.

5 Die leiers in die Nederlandse kerke van Gereformeerde oortuiging, was verdeeld oor die twee uiteenlopende standpunte soos verteenwoordig deur die Remonstrante, later bekend as die Arminiane en die behoudendes. Dit sou lei tot een van die belangrikste kerkvergaderings in die geskiedenis van die Gereformeerde Kerk wêreldwyd. Gedurende 1618-1619 het kerkleiers byeengekom om die standpunte van die Remonstrante te weeg. Die resultaat van hierdie vergadering is wat vandag algemeen bekend staan as die Dordtse Leerreëls. Aangesien die Remonstrante se protes in die vorm van vyf artikels verwoord was, het die Dordtse Sinode elkeen van daardie artikels weerlê en die sogenaamde regsinnige leer aangebied. Vandaar die vyf punte wat deur die Dordtse Leerreëls aangebied word. Later sou hierdie vyf punte volgens die akroniem TULI.P bekend staan as gevolg die inhoud van elke punt.

6 Dordtse Leerreëls II.3-4, 8 wys daarop dat die versoening genoegsaam is vir die wêreld maar net effektief is in die lewe van die uitverkorenes.

7 Die Supralapsarisme aanvaar dat die uitverkiesingsbesluit die sondeval noodsaaklik gemaak het; die infralapsarisme wys dit af. Die infralapsarisme bly egter binne dieselfde skolastieke denkstruktuur as die Supralapsarisme maar is slegs minder konsekwent. Die sondeval is eerder passief as aktief in die raad van God opgeneem. Die diskriminasie tussen uitverkorenes en verworpenes is nie die eerste gedagte van God nie, maar volg eers later en het dan betrekking op mense wat almal sondaars is en geen genade verdien nie (Hodge 1875:318). 
This book could well be the most important book written in the twenty-first century for all evangelical Christians to read ( Hunt 2002:1)

\subsection{Die opkoms van die Nuwe Calvinisme (New Calvinism)}

In Time Magazine van 12 Maart 2009 word "10 ideas changing the world right now" gelys en bespreek. Die Nuwe Calvinisme (New Calvinism) as een van hierdie idees word ook onder die loep geneem. Ted Olsen, 'n besturende redakteur van Christianity Today word deur Van Biema (2009) aangehaal wanneer hy sê: "Everyone knows where the energy and the passion are in the Evangelical world". Dan beskryf Van Biema hierdie energie en passie met verwysing na John Piper, Gereformeerde Baptis van Minneapolis, Seattle se veelbesproke Mark Driscoll en Albert Mohler, hoof van die Southern Seminary van die massiewe Southern Baptist Convention. Die ESV Studiebybel word ook betrek en daar word opgemerk dat gereformeerde "blogs" soos Between the Two worlds van die kuber-Christendom se mees populêre besoekpunte is.

Die kern van die artikel word soos volg deur van Biema (2009) beskryf:

Calvinism is back, and not just musically. John Calvin's 16th century reply to medieval Catholicism's buy-your-way-out-ofpurgatory excesses is Evangelicalism's latest success story, complete with an utterly sovereign and micromanaging deity, sinful and puny humanity, and the combination's logical consequence, predestination: the belief that before time's dawn, God decided whom he would save (or not), unaffected by any subsequent human action or decision.

Op 3 Januarie 2014 word in The New York Times 'n artikel, Evangelicals find themselves in the midst of a Calvinist revival gepubliseer.

Oppenheimer (2014) dui aan dat Calvinisme met rasse skrede toeneem in die VSA, met 'n geweldige toename in lidmaatgetalle.

Tydens die sewende jaarlikse Richard Gaffin-lesing oor teologie, kultuur en sending by Westminster Theological Seminary in Maart 2014, het John Piper 'n lesing gelewer met die titel, "The New Calvinism and the New Community: The Doctrines of Grace and the Meaning of Race." In 
sy lesing gee hy 'n beskrywing van die kenmerke van Nuwe Calvinisme (New Calvinism). Hierdie kenmerke is bloot beskrywend en nie in enige sin voorskriftelik of 'n evaluering van die beweging ten opsigte van "Ou Calvinisme" nie.

Vir die doeleindes van hierdie artikel is dit van belang om veral na die eerste twee van die 12 stellings ${ }^{8}$ van Piper te kyk (Oliphint 2014).

The New Calvinism, in its allegiance to the inerrancy of the Bible, embraces the biblical truths behind the five points (TULIP), while having an aversion to using the acronym or any other systematic packaging, along with a sometimes qualified embrace of limited atonement. The focus is on Calvinistic soteriology but not to the exclusion or the appreciation of the broader scope of Calvin's vision.

8 Die ander stellings wat deur Piper gemaak is, is die volgende: “The New Calvinism has a strong complementarian flavour as opposed to egalitarian, with an emphasis on the flourishing of men and women in relationships where men embrace a call to robust, humble, Christ-like servant leadership. The New Calvinism leans toward being culture-affirming rather than culture-denying, while holding fast to some very culturally alien positions, like positions on same-sex practice and abortion. The New Calvinism embraces the essential place of the local church. It is led mainly by pastors, has a vibrant church-planting bent, produces widely-sung worship music, and exalts the preached word as central to the work of God locally and globally. The New Calvinism is aggressively mission-driven, including missional impact on social evils, evangelistic impact on personal networks, and missionary impact on unreached peoples of the world. The New Calvinism is inter-denominational with a strong (some would say oxymoronic) Baptistic element. The New Calvinism includes charismatics and noncharismatics. The New Calvinism puts a priority on pietism or piety in the Puritan vein, with an emphasis on the essential role of affections in Christian living, while esteeming the life of the mind and being very productive in it, and embracing the value of serious scholarship. Jonathan Edwards would be invoked as a model of this combination of the affections and the life of the mind more often than John Calvin, whether that's fair to Calvin or not. The New Calvinism is vibrantly engaged in publishing books and even more remarkably in the world of the internet, with hundreds of energetic bloggers and social media activists, with Twitter as the increasingly default way of signalling things new and old that should be noticed and read. The New Calvinism is international in scope, multi-ethnic in expression, culturally diverse. There is no single geographic, racial, cultural governing centre. There are no officers, no organization, nor any loose affiliation that would encompass the whole. I would dare say that there are outcroppings of this movement that nobody (including me) in this room has ever heard of. The New Calvinism is robustly gospel-centred, cross-centred, with dozens of books rolling off the presses, coming at the gospel from every conceivable angle, and applying it to all areas of life with a commitment to seeing the historic doctrine of justification, finding its fruit in sanctification personally and communally." 
The New Calvinism embraces the sovereignty of God in salvation, and in all the affairs of life in history, including evil and suffering.

Dit is duidelik uit die formulering van die eerste stelling dat daar 'n bewustheid is van die feit dat TULIP en veral dan beperkte versoening problematies is en kan veroorsaak dat andersins eensgesinde gelowiges uit evangeliese kringe hulle van die beweging mag distansieer. Hierdie formulering los egter nie die problematiek op nie, maar veroorsaak groter spanning. Dit is geen geheim dat die Nuwe Calviniste die sterkste ondersteuning vanuit die sogenaamde Gereformeerde Baptiste-kringe kry nie. Piper erken dit ook in sy sewende stelling: "The New Calvinism is inter-denominational with a strong (some would say oxymoronic) Baptistic element" (Oliphint 2014).

Die Presbiteriane sowel as die Gereformeerde Baptiste onder hierdie beweging, se belydenisskrifte ${ }^{9}$ onderskryf egter duidelik dit wat in TULIP opgesom word.

Die Westminster Confession of Faith (WCF) (par. 3.3) stel dit soos volg:

By the decree of God, for the manifestation of His glory, some men and angels are predestined unto everlasting life and other foreordained to everlasting death.

Die Baptist Confession of Faith (BCF) van 1689 bevat die presiese bewoording in paragraaf 3.3 maar voeg na "predestined" die volgende by: "or foreordained to eternal life through Jesus Christ ..."

In WCF (par.4.4) en BCF (par.4.4) lees dit weer:

These angels and men, thus predestinated, and foreordained, are particularly and unchangeably designed, and their number so certain and definite, that it cannot be either increased or diminished.

9 Aucamp (2011:234-238) wys weer daarop dat Gereformeerde Baptiste in Suid-Afrika, wat almal die 1689 Baptiste Geloofsbelydenis onderskryf ook 'n nuwe opbloei beleef as gevolg van die sogenaamde Sola 5 affiliasie van eendersdenkende gemeentes wat in 2005 tot stand gekom het. Sola 5 is egter nie beperk tot Suid-Afrika nie maar bestaan ook uit geaffilieerde gemeentes in Swaziland, Malawi, Mosambiek, Namibië, Zambië en Zimbabwe. Daar is steeds konstante groei in die getal gemeentes wat deel word van hierdie affiliasie. 
In die lig van hierdie uitsprake deur gerespekteerde belydenisse binne die evangeliese wêreld kom die aanvalle op Nuwe Calvinisme geensins as 'n verrassing nie. Fahy (2014:3) stel dit duidelik in sy artikel, "New Calvinism is not like Calvin":

New Calvinists deny both the obvious words of the Bible, the clear statements of Calvin and the words in the confessions by denying reprobation. In denying this they are besmirching God's glory and also calling God a liar. God is glorified in his reprobation of those condemned just as much as his election of saints.

TULIP veroorsaak dus 'n probleem. As jy dit binne die evangeliese dampkring onderskryf of huiwerig is om dit onveranderlik te onderskryf, ontstaan die vraag of die wese van God en die wese van die mens nie op die een of ander wyse hierdeur aangetas word nie.

Ten spyte van die Nuwe Calviniste (New Calvinists) se begeerte om absoluut missionêr te wees en oor denominasionele grense te werk dui Merritt (2014) onrusbarende tendense binne hierdie beweging aan. Hy lig wat hy noem isolasionisme (isolationism), stamwese (tribalism) en eiewaan/egotisme (egotism) uit as die sterkste van hierdie tendense. Koning en Buys (2016 6-7) wys op 'n gebrek aan nuwe bekeerlinge en die geneigdheid tot isolasie en die gebrek aan kontekstualisering binne Gereformeerde Baptiste kringe in Suid-Afrika.

Dit is sekerlik nie moontlik om definitiewe uitsprake te lewer oor wat die oorsaak van genoemde verskynsels is nie, maar die vraag kom tog op of genoemde paragrawe in die WCF en die BCF die klimaat waarin die Skrif oor mense en die redding van mense praat laat deurskemer of weerspreek en of dit nie tog 'n invloed het op die praktyk van kerkwees in hierdie wêreld onder sekere evangeliese Christene en daarom ook onder sekere Nuwe Calviniste (New Calvinists) nie.

Het dit nie tyd geword om te herbesin oor God se verkiesing en die verband daarmee met Sy verbondsomgang met die mens nie? In hierdie studie word die oortuiging uitgespreek dat die oplossing vir die dilemma wat TULIP op verskeie vlakke veroorsaak effektief aangespreek en hanteer kan word deur 'n waardering en toepassing van die teologie van Heinrich Bullinger. 


\section{Waarom Heinrich Bullinger?}

Volgens Venema (2005: 127-128) en Mock (2013:9-17) is Bullinger verreweg die mees bemiddelende, gematigde en pastoraal gefokusde van al die reformatore. Al sy teologie was uiteindelik Christus-gesentreerd en kon gepreek word.

Mock (2013:1-35) toon ook aan dat Bullinger 'n onafhanklike Bybelse teoloog sonder gelyke in die 16de eeu was. Kirby (2004:110) wys op die fassinerende verskynsel dat waar Zwingli predestinasie in die konteks van kontroversie ontwikkel het, Bullinger die leerstelling self as 'n bron van kontroversie of weerspreking sien. Hy wys daarop dat Bullinger uiters versigtig met die uitverkiesing te werk gaan en dat hy:

... rejects 'curious questions' while pointing to what God has revealed both of Himself and his will. Bullinger's presentation is always Christological in emphasis: election is 'in Christ'.

Responsibility for lack of faith is not in God's will but in the human will. God's desire is for all to be saved. Bullinger consistently opposes any suggestion that God is the author of sin or evil and equally opposes any suggestion that we can be the author of our salvation which is wholly dependent on divine agency (Kirby 2004:110)

Uit bogenoemde aanhaling blyk dit dat Bullinger die aangewese teoloog is om aan te toon hoe God se verkiesing versoenbaar is met die sterk klem wat die Bybel op die mens se verantwoordelikheid plaas en die vraag of God se verkiesing in ooreenstemming is met sy goedheid.

Bullinger met sy unieke klem op die verbond en sy Christologiese hantering van die verkiesing in samehang met die verbond, hanteer die uitverkiesing op 'n wyse wat nie die wese van God en die wese van die mens aantas nie.

Die voordeel daarvan om Bullinger te betrek is juis ook daarin geleë dat hy nie geassosieer word met die vooropgestelde idees rondom Calvyn en Calvinisme nie.

Bullinger se verbondsleer gaan nou eerstens onder die loep kom en daarna sy uitverkiesingsleer. Die volgorde is doelbewus aangesien daar aangedui gaan word dat Bullinger se verstaan van die verbond juis sy uitverkiesingsleer beïnvloed en binne 'n meer Bybelse getroue raamwerk 
plaas. Ten slotte sal daar dan met 'n paar implikasies wat dit vir evangeliese Christene inhou, volstaan word.

\section{Bullinger se verbondsleer}

Vos (1980:236) maak die insiggewende opmerking dat die teologie van Calvyn gebou is op die basis van die Drie-eenheid (Triniteit) en juis daarom kon die verbond nie as dominante beginsel in sy teologie na vore kom nie.

Wanneer daar na Bullinger se werke gekyk word, is dit duidelik dat die verbond die dominante beginsel in sy teologie is, omrede hy die verbond as die hooftema van die Bybel sien.

Vir die doeleindes van hierdie artikel is dit belangrik om daarop te let dat Bullinger in sy mees bekende werk oor die verbond, De testamento seu foedere Dei unico et aeterno (1534) of dan soos die Engelse titel lui: $A$ brief exposition of the one and eternal testament or covenant of God, ${ }^{10} \mathrm{vyf}$ hoofpunte van die verbond uitlig.

- Eerstens beklemtoon hy dat daar een verbond in die geskiedenis is, wat eerstens met Adam gesluit is, vernuwe is met Abraham en dwarsdeur die Ou Testament aanwesig is. Uiteindelik vervul en vernuwe Christus hierdie verbond en word dit gepredik deur die apostels.

- Tweedens is hierdie verbond bilateraal van aard. Aan die een kant beloof God om algenoegsaam te wees, wat natuurlik in Christus vervul is. Die verbond is ook voorwaardelik in die sin dat mense in geloof en liefde op God se beloftes moet antwoord.

- Derdens is die verbond die onderwerp van die hele Skrif wat die doelwit is wat die hele Skrif nastreef.

- Vierdens is die ou sakramente van die verbond, besnydenis en die Pasga vervang deur Christus, deur die doop en die Nagmaal.

10 'n Engelse vertaling deur Charles S. McCoy and J. Wayne Baker word gevind in Charles S. McCoy en J. Wayne Baker se Fountainhead of Federalism: Heinrich Bullinger and the Covenant Tradition (Louisville, Kentucky: Westminster/John Knox Press, 1991), pp. 101-138. In hierdie artikel sal die bladsynommer van Bullinger se Brief Exposition/De testamento seu foedere, die bladsy nommer wees soos gevind in The Fountainhead of Federalism, bv Bullinger 1991: (bladsy) 
- Vyfdens is die Christelike geloof volgens hom die essensie van die verbond wat eerste met Adam gesluit is. Hy vat die belangrikheid van hierdie vyf punte van die verbond soos volg saam:

"The entire sum of piety consists in these very brief main parts of the covenant. Indeed, it is evident that nothing else was handed down to the saints of all ages, throughout the entire Scripture, other than what is included in these main points of the covenant, although each point is set forth more profusely and more clearly in the succession of times" (Bullinger 1991:112).

Dit is egter nie net in hierdie werk wat die verbond toonaangewend is nie. Vos (1980:235) merk op dat Bullinger se Decades (1549-1551) 'n werk is, soos hy dit stel, "structured entirely by the covenant idea." Dat Gordon \& Campi (2004:6) opmerk dat "the Bullinger of the Decades is Bullinger himself, more truly than in any other major writing" beklemtoon dat die verbond 'n geweldige rol speel in die verstaan van Bullinger. Baker (1998:62-66) toon oortuigend aan dat die verbond ook absoluut prominent is in sy Summa van 1556 en sy Kategismus van 1559.

Belangrik vir hierdie studie is egter om te let op Bullinger se Christologiese fokus as dit kom by die verbond, aangesien 'n fokus op Christus en verkiesing in Hom determinisme hokslaan.

Wat uitstaan in sy bespreking van die verbond is dat Jesus die ware saad van Abraham en ook die saad van Eva is. Jesus is die belofte aan Eva en Abraham. Die implikasie: Kinders van die belofte (Rom. 9) is die wat gekoppel is aan Jesus deur die geloof, geloof in die belofte! (Mock 2013:1617).

Met verwysing na Galasiërs 3:16 sê Bullinger:

Abraham was promised the Lord Jesus, in whom is all fullness, righteousness, sanctification, life, redemption, and salvation (I Cor. 1:30), of whose fullness we have all received, grace for grace (John 1:16), because it pleased the Father that all fullness dwell in him, and through his blood on the cross he has made peace with everything that is in heaven and on earth (Col. 1:19-20; Bullinger 1991:110).

Hy stel dit duidelik dat "in the one and eternal covenant of God, Jesus is the inheritance itself” (Bullinger 1991:110). 
Jaroslav Pelikan (1984:243) wys daarop dat Bullinger se siening van die verbond sy fokuspunt vind in die Verlosser. Met die gebruikmaking van sommige van die Switser se woorde en frases som hy Bullinger se posisie soos volg op:

Christ [is] the 'consummation' of the covenant, for in him it [has] appeared "most excellently, purely, and clearly of all."

Ook Opitz (2004:333) kom tot die gevolgtrekking dat Christus vir Bullinger die vervulling van die verbond is ${ }^{11}$.

In sy De testamento seu foedere Dei unico et aeterno, beskou Bullinger God se verbond met sy mense as bevestig in die menswording van die Seun van God:

What am I to say about Christ the Lord, who, not only in every teaching but also in his most astounding incarnation, explained and confirmed in a marvellous and living way that eternal covenant of God made with the human race? For when the true God assumed true humanity, then he no longer acted with words or arguments, but by that very event he bore witness to the greatest mystery in the entire world, namely, that God admitted humans into the covenant and into partnership, indeed that he bound them to himself with an indissoluble bond by the highest miracle of love, and that he is our God. Thence, truly we also believe the name given to Christ in Isaiah (7:14), when he is called "Emmanuel", which is to say, "God with us" (Bullinger 1991:114).

Dit is dus uiters belangrik om raak te sien dat die verbond 'n sentrale rol speel by Bullinger maar nie as 'n filosofiese of logiese konsep nie, eerder as 'n historiese een en boweal as 'n Christologiese konsep.

Bullinger het inderdaad die leer van die verbond op die agenda van Gereformeerdes se belydenis geplaas. Teen die vroeë 1560's het geen belydenis van geloof die leer van die verbond op enige betekenisvolle manier geïnkorporeer nie. Die Heidelbergse Kategismus, wat in 1563 gepubliseer is, verwys net amper terloops hierna. Dieselfde is waar van die Scottish

11 Die implikasie hiervan is natuurlik dat Jesus die twee kante van die verbond, naamlik: "Ek wil vir jou 'n God wees" en "Jy moet vir my 'n volk wees" oorneem en vul tot die volheid wat God daarvoor bedoel het. 
Confession en die Belgic Confession van 1561. Toe die Second Helvitic Confession in 1566 gepubliseer is, was Bullinger die enigste Gereformeerde leier wat 'n werk oor die verbond daargestel het. Dit was eers in the 1570's en 1580's dat Ursinus en Olevianus die konsep begin gebruik het. ${ }^{12}$

\author{
Latere formulerings rondom die verbond toon betekenisvolle afwykings \\ van Bullinger se verbondsleer (Diemer 1935:23-30). Betekenisvol vir \\ hierdie studie is die feit dat die Westminster Confession wat 'n invloed in \\ die Nuwe Calvinistiese (New Calvinist) kringe het, uitverkiesing nie soseer
}

12 Ons sien egter al reeds by Melancthon 'n afwyking van Bullinger se verbondsiening. Diemer (1935:23-30) toon aan dat hy reeds teruggryp na die skolasties-Aristoteliaanse natuur/genade paradigma. Waar Bullinger van een genadeverbond praat, maak Melanchton nou onderskeid tussen 'n algemene verbond (foedus generale) wat God met die mens en die skepping vóór die sondeval gemaak het en waar die natuurwet geld, en 'n spesiale verbond (foedus speciale) wat van ewigheid geld en wat opgerig is met die uitverkorenes op 'n basis wat deur God alleen bepaal word. Dit is egter Ursinus wat die gedagte van 'n dubbele verbond (Doppelbund) sedert 1562 vaslê. Zacharias Ursinus (1534-83), wat aanvanklik onder Philip Melanchthon in Wittenberg studeer, word in 1562 die eerste teoloog wat in sy Kategismus onderskei tussen 'n foedus naturale (natuurverbond) wat by die skepping van die mens tussen God en die mens tot stand gekom het, en die foedus gratia of genadeverbond wat ná die val in werking tree. Hy gebruik dus 'n pre-lapsariese verbond as 'n manier om Genesis 1 tot 3 se verhaal van die mens voor die sondeval te interpreteer, in teenstelling met Bullinger wat net werk met die genadeverbond as 'n post-lapsariese verbond wat met sondaars ná die val gesluit is. Die belofte daarvan is, soos reeds gesien, vervul in Christus (Torrance 1994:21). Vir die eerste keer in die gereformeerde tradisie is die term foedus gebruik om die skepping en menslike bestaan vóór die val te interpreteer. Ursinus se medeprofessor, Kaspar Olevianus (1536-87), leer ook dat God met Adam 'n verbond aangegaan het, en noem dit weer die foedus creationis, of skeppingsverbond (Jonker, 1989:84; McCoy \& Baker, 1991:39). Vir sowel Ursinus as Olevianus is die konsep van 'n verbond egter nog nie 'n koördinerende beginsel in hul teologie nie. Daar is geen verwysing daarna in die Heidelbergse Kategismus of in Pareu se kommentaar op Ursinus se Kategismus nie (Torrance 1994:23).Voor die einde van die 16de eeu verkry dit egter juis so 'n oorheersende funksie onder die Engelse Puritanisme en in die Skotse verbondstradisie. In 1585 publiseer Fenner sy Sacra Theologia, met 'n voorwoord deur Thomas Cartwright. Volgens Torrance (1994:24) is dit die eerste werk waarvan ons weet wat die term "covenant of works" (foedus operum), of "the covenant of law," gebruik. Dat die hele federale gedagte van die leer van die twee verbonde al belangriker word, word ook duidelik deur die feit dat James Ussher (1581-1656), saam met Perkins en Ames van die toonaangewende Federaliste aan die begin van die sewentiende eeu die sogenaamde Ierse Artikels van 1615 saamstel. Hierdie artikels is in effek die eerste geloofsbelydenis wat eksplisiet die "verbond van werke" terminologie gebruik. Hierdie artikels berei nie net die weg voor vir die opstel van die Westminster Confession, wat betref die federale gedagte nie, maar voorsien ook die basiese orde en struktuur van die Westminster Confession (Mitchell 1838:117). Om die waarheid te sê was dit nie tot en met die daarstelling van die Westminster Confession of Faith van 1647 dat die verbond 'n prominente rol in Gereformeerde belydenis begin speel het nie. 
histories en Christologies hanteer as onlosmaaklik verbonde aan die een verbond nie, maar dit eerder sien as die een ewige kant van predestinasie teenoor die ewige verwerping. Dit is heel moontlik dat die Westminster Confession of Faith se uitverkiesingsleer anders daar sou uitsien indien Bullinger se verbondsleer nagevolg is.

\section{Bullinger en die uitverkiesing}

Dit is uiters belangrik vir die debat onder bespreking dat evangeliese Christene sal verstaan dat Bullinger nie soseer 'n alternatiewe siening van uitverkiesing naas Calvyn daarstel nie, maar dat dit eerder Calvyn was wat 'n alternatiewe leerstelling van uitverkiesing of dan predestinasie binne die gereformeerde tradisie op die tafel geplaas het (Baker 1998:374).

Maar wat leer Bullinger?

Uit 'n bestudering van Bullinger se Decades word dit alreeds duidelik dat Bullinger bevestig dat die evangeliese aanbod universeel is. Die genade van Christus word vir almal aangebied. Die wat dit verwerp doen dit uit vrye wil, nie omrede God so 'n dekreet daargestel het nie. Hy bevestig ook dat diegene wat geloof beoefen, die uitverkorenes is wat deur God se genade gered word. Ten diepste beteken uitverkiesing dus insluiting in die volk van God, maar nie die ander kant van die munt naamlik uitsluiting nie (Baker 1980:332-335). Daar is wel navorsers wat deur die jare geargumenteer het dat Bullinger uiteindelik Calvyn se dubbele predestinasie aanvaar het (Schweizer 1854: 291,459; Donnelly 1976:184 en Moltmann 1961:100-103).

Dit is te verstane as daar gekyk word na wat Bullinger in die Decades skryf:

Predestination is the eternal decree of God by which He determined either to save or to destroy men, a most certain end of life death already having been provided (Baker 1998:70).

Baker (1980:34) haal egter vir Bullinger aan waar hy elders in die Decades skryf:

Christ and the grace of God announced or declared by the gospel belongs to everyone. For no one should imagine that two books are put aside in heaven, in the first of which those are inscribed who are ordained to be saved, and even must be saved by necessity, without 
question...; and in the second those recorded to be condemned are kept, who cannot escape condemnation, no matter how piously the might live. Let us rather hold that the holy gospel of Christ proclaims the grace of God, the remission of sins, and eternal life in general to the entire world.

In 1554 bevestig hy dat geloof die bewys van uitverkiesing is; hy bevestig universele versoening en herhaal dat mense verwerp word as gevolg van hulle eie sonde en die feit dat hulle nie glo nie (Bullinger 1554: De gratia Dei fol. 612-13,28-28b).

In 1558 beklemtoon Bullinger die universele versoening en waarsku teen spekulasie omtrent die geheime raadsplan van God (Bullinger 1558: Sermones, fol.8-10,172).

'n Paar jaar later vind ons ook hierdie fokus in sy Jesaja-kommentaar. In sy kommentaar op Jesaja 1 beklemtoon hy God se vrye verkiesing in Christus op grond van genade alleen (Bullinger 1567: Isaias fol.7b). 'n Paar bladsye verder skryf hy egter: "God wil nie die dood van sondaars, maar wil eerder dat hulle bekeer en lewe"13 ( Baker 1998:71; Bullinger 1567: Isaias fol.10b).

In sy kommentaar oor Jesaja 6:10-13 maak hy dit duidelik dat God se oordeel en verwerping van die Jode nie beteken dat God die oorsprong van die kwaad is nie. Die Jode is verwerp as gevolg van hulle eie sonde en dieselfde is waar van individue. Die uitverkorenes, volgens Bullinger, is die persone, beide in die Ou en Nuwe Testament, wat deur Christus die geseënde saad na God draai. God verwerp die wat in sonde en ongeloof bly (Bullinger 1567: Isaias, fol. 35-36b). Weer en weer word dit duidelik dat verkiesing en verwerping nooit losgemaak kan word van Christus nie: “... want Christus roep elkeen na Hom, maar mense aanvaar Hom nie. Dit is die oorsaak van ons verwerping"14 (Baker 1998:72; Bullinger 1567: Isaias fol. 250b-251).

13 Eie Afrikaanse vertaling van Baker 1998:71 se Engelse vertaling van Bullinger in sy kommentaar op Jesaja.

14 Eie Afrikaanse vertaling van Baker 1998:71 se Engelse vertaling van Bullinger in sy kommentaar op Jesaja. 
Dit is miskien ook die moeite werd om net te verwys na sy kommentaar op Jesaja 53 waar Bullinger die universele versoening van Christus beklemtoon (Bullinger 1567:Isaias fol. 266b).

Hand aan hand hiermee gaan die universele roeping, waarna Bullinger in sy kommentaar oor Jesaja 55 verwys. God roep almal, alhoewel baie nie reageer nie. (Bullinger 1567: Isaias fol. 275b). Hierdie roeping vind natuurlik plaas deur die verkondiging van die evangelieboodskap.

Wat uiters belangrik is om raak te sien, is dat Bullinger die universele roeping wat tot almal uitgaan, verbind aan die ewige verbond wat God met die mens gesluit het: "Want lewe kom vanaf die ewige verbond ... Die belofte aan Dawid is Christus ... Alle mense van alle tye word geroep na Christus $^{15}$ (Baker 1998: 72; Bullinger 1567:Isaias fol. 277b).

Dat Bullinger se idees oor verkiesing en veral ook verwerping verskil het van dié van Calvyn en ander soos Beza, het eintlik eers begin duidelik word na sy debatte met Calvyn oor hierdie onderwerp. Pighius, Bolsec en Castellio voer ook hieroor debatte met Calvyn. Al vier se beswaar is ten diepste dat Calvyn in sy uitverkiesings- en voorsienigheidsleer teen die Skrif ingaan aangesien dit die vrye wil van die mens en die goedheid van God aantas (Diedericks 2014:1-9). Hier moet onthou word wat deur Helm (1994:393) uitgelig word as hy aantoon dat Calvyn die uitverkiesing en die voorsienigheid as twee kante van dieselfde munt beskou.

Dit sou egter ook moontlik wees om aan te dui dat Calvyn, of ten minste heelparty van Calvyn se uitsprake, nader aan Bullinger se pastorale benadering kom as wat gedink mag word. Ook by Calvyn moet sy siening oor predestinasie waarskynlik saamgelees word met sy ander sieninge oor Christus en die uitverkiesing. ${ }^{16}$ Dit is egter nie die doel van hierdie studie om in 'n debat hieroor te verval nie. Die feit bly staan dat Bullinger van

15 Eie Afrikaanse vertaling van Baker 1998:72 se Engelse vertaling van Bullinger in sy kommentaar op Jesaja.

16 Calvyn se definisie van die predestinasie lui soos volg: "Predestinasie noem ons die ewige besluit van God waardeur Hy by Homself vasgestel het wat Hy wil hê van elke mens moet geskied. Want alle mense word nie onder dieselfde toestand geskep nie, maar vir sommige is die ewige lewe, vir andere die ewige verdoemenis bestem. Namate elkeen dus vir die een of ander doel geskep is, sê ons dat hy òf vir die lewe of vir die dood voorbestem is" (Calvyn 1984: Inst. 3, 21,5). Tog maak hy ook die uitspraak dat Christus as die spieël van die uitverkiesing verstaan moet word (Calvyn 1984: Inst.3.24,5-6) 
Calvyn verskil, soos gesien uit die debatte en veral ook met Beza se denke wat as supralapsaries ${ }^{17}$ beskryf kan word en heilsekerheid ook onder druk plaas. Hierdie nalating beïnvloed steeds evangeliese Christene via die WCF en $B C F$ (vgl. WCF en BCF par.18.3) en het ongetwyfeld op een of ander wyse 'n rol gespeel in die uiteindelike formulering van TULIP.

\section{Bullinger se bydrae tot die verhouding verbond en verkiesing}

Dat Bullinger uitverkiesing en verbond op mekaar betrek en sodoende beide in 'n meer Bybelse perspektief plaas as wat van die ander Reformatore doen, is duidelik en moet van naderby beskou word.

\subsection{Die verbond as historiese ruimte waarbinne die uitverkiesing plaasvind}

Dit is duidelik dat Bullinger nie verkiesing en verbond totaal wil laat saamval in so mate dat die een agter die ander verdwyn nie. Hy wil baie duidelik nie uitwys dat alle mense in die verbond met God opgeneem is en daarom ook in Christus reeds uitverkies is nie.

Met die begrip uitverkiesing wil hy steeds die volle klem op die vrymagtige beskikking van God oor sy volk wat voorafgegaan aan en onthef is van alle menslike kwaliteite of handelinge, handhaaf.

Dit is egter hier waar die inbring van die verbond deurslaggewend is. Die begrip verbond lê daarteenoor klem daarop dat God vir Hom 'n volk in die geskiedenis afgesonder het met wie Hy in 'n gemeenskap van liefde en trou wil verkeer. Dit is natuurlik self ook deel van sy vrymagtige genade. Die uitverkiesing staan agter hierdie verbond want die gemeenskap van God met sy volk in die geskiedenis spruit voort uit sy ewige liefde en is daarom daarop gemik om 'n ewige verhouding te wees.

By Bullinger is die verbond daarom eintlik'n gestalte van die uitverkiesing. Dit is die gestalte van die uitverkiesing in die geskiedenis. So word God se ewige beslissing binne tyd gebring. So verleen die verkiesing aan die

17 Die supralapsarisme verstaan die uitverkiesing en verwerping as die uitgangspunt van al God se weë met die mens en die wêreld. Dit gaan God se besluit om te skep en sy besluit om toe te laat dat die mens in sonde val vooraf (Weber 1951:119). 
verbond sy karakter van vastigheid wat gegrond is in God se ewige keuse en trou, maar die verbond verleen weer aan die uitverkiesing die karakter van 'n dinamiese werklikheid wat in die geskiedenis van God se omgang met sy volk voltrek word. Uitverkiesing en verbond word dus op mekaar betrek en tog word ruimte gelaat vir die ongeloofsbreuk binne die verbond sonder om die verbondsbeloftes te relativeer (vgl. Jonker 1989:181,184).

\subsection{Kerugmatiese universaliteit}

Hierdie dinamiese karakter van die uitverkiesing word by Bullinger duidelik wanneer hy uitverkiesing met die prediking en roeping verbind, wat weer binne die raamwerk van die verbond plaasvind waar die bondgenoot in geloof en bekering op die liefdevolle aanbod kan antwoord òf dit in ongeloof kan verwerp (vgl. Bullinger 1567: Isaias fol. 277b).

Dit kan soos volg omskryf word. Die prediking het natuurlik as inhoud Christus. Die heil word dan ook ontvang in die werking wat die Persoon van Jesus Christus deur die Heilige Gees op die mens uitoefen. Die mens word hierdeur vrygemaak om in sy eie verantwoordelikheid in geloof en bekering te antwoord. Hierdie roeping is dan ook 'n gestalte van die uitverkiesing.

Anders as by die predestinasie vind die verwerping, volgens Bullinger se siening, ook in hierdie situasie plaas. Die mens kan op onverklaarbare wyse nee sê vir hierdie aanbod. Aangesien die geskiedenis nie 'n selfstandige party teenoor God is nie, staan ook hierdie ongeloof van die mens nie los van God se heerskappy nie. Dit gaan egter tog teen God se bedoeling in.

Die voordeel hiervan is dat die prediking 'n oop situasie word waarin Christus sy gemeente deur sy Woord en Gees versamel in 'n proses waarin die Woord skiftend en skeidend tussen die mense in die geskiedenis werksaam is.

Duidelik kan daar binne hierdie verstaansraamwerk nie oor die versoening op die manier van die partikularisme gepraat word nie. Die gedagte dat Christus se versoening tot 'n voorafbepaalde getal uitverkorenes beperk is, pas nie binne Bullinger se raamwerk nie. Inderdaad kan daar aan die universalistiese tekste van die Skrif alleen reg laat geskied word as dit verstaan word asof God se roeping tot alle mense uitgaan. Soos Berkouwer (1955:290) dit stel: In die antwoord op die algemene prediking van die 
heil word die vryheid van God se verkiesing sigbaar. Dit is nie meer nodig om aan 'n geslote aantal uitverkorenes te dink nie, aangesien die getal aan God se genade en beslissing oorgelaat word. Beide partikularisme en universalisme se polêre denke word in Bullinger se denke losgelaat. Die soewereiniteit van God en die verantwoordelikheid van die mens kan albei gehandhaaf word in 'n visie op die verband tussen genade en geloof waarin God die volledige inisiatief het en die menslike geloof suiwer reseptief en nie-kreatief betrokke is op God se roeping deur sy Gees en Woord binne die konteks van die verbond.

\subsection{Die verkiesing van Christus en sy gemeente}

Die klem van Bullinger dat die uitverkiesing in Christus plaasvind, veroorsaak dat daar nie agter Christus 'n uitverkiesingsbesluit bestaan wat verborge is nie. Die uitverkiesing is in Christus geopenbaar en elkeen wat in Hom glo, besit die versekering dat hy saam met Christus en in Hom uitverkies is. Christus is die kengrond van die verkiesingsbesluit van God.

Voorts moet Christus en die uitverkorenes as 'n eenheid gesien word. Daar is nie ' $n$ besluit waarin 'n sekere aantal mense uitverkies is wat voorafgaan aan die verkiesing van Christus tot Hoof en Middelaar nie. Die logiese uitvloeisel van Bullinger se denke is dat daar maar een besluit van verkiesing is waarin Christus en die wat aan Hom behoort, uitverkies is. Christus en Sy gemeente is uitgekies. Die verkiesing van Christus gaan egter die verkiesing van die gemeente vooraf. Kortom: Die implikasie is duidelik. Vir Bullinger is om uitverkies te wees en in Christus te wees, dieselfde saak. Omgekeerd is om buite Christus te wees en verworpe te wees dieselfde (Walser 1957:279).

\subsection{Jesus die uitverkore saad en die verbond}

Om alles weer vanuit die hoek van die verbond te beskryf, kan die volgende opmerkings gemaak word. God se mense onder die ou verbond en die nuwe verbond is kinders van die "belofte." Dit word sterk deur Bullinger beklemtoon (vgl. Mock 2013:16-17).

Die belofte is egter niks anders as die nageslag deur wie die wêreld geseën sal word nie (Gen. 12 15, 17, 22), en dit is ten diepste Jesus! Die saad. Hierdie saad is natuurlik korporatief. Jesus en diegene wat aan Hom behoort, Jesus en sy liggaam (Gal. 3:16) (Bullinger 1991:110). 
Hoe word jy ware kind van Abraham? As jy in die belofte glo, as jy in Jesus is. Dit is die wat geroep is. Wie uitgekies is.

Paulus stel dit duidelik in Galasiërs 3:29: "En as julle aan Christus behoort, dan is julle die nageslag van Abraham en volgens die belofte erfgename."

Bullinger(1991:114) redeneer baie duidelik dat Jesus self die verbond tussen God en mens is.

Die inhoud van die verbond, "Ek sal vir julle 'n God wees, en julle sal vir My'n volk wees" is dus Jesus Christus en dit word (in albei dele) in en deur Jesus Christus vervul!

\section{Enkele implikasies vir die evangeliese Christendom}

- Bullinger se denke kan evangeliese Christene help om nie bewustelik of onbewustelik die Arminiaanse standpunt as die enigste alternatief vir TULIP te sien nie. Dit help om aan evangeliese Christene 'n alternatiewe gereformeerde beskouing te gee wat meer Skrifgetrou daar uitsien. Dit is duidelik dat die idee van 'n absolute dekreet vir Bullinger net so onaanvaarbaar as vir die Arminiane is. Hy verskil egter van die Arminiane en is meer Skrifgetrou hierin, wanneer hy nie die vooruitgesiene geloof in Christus as die grondslag vir die uitverkiesing sien, soos die Arminiane nie (vgl. Jonker 1989:71). Volgens hierdie denkrigting kry geloof in Christus 'n verdienstelike karakter met die oog op die uitverkiesing. Daarmee saam word daar ook geredeneer dat Christus God moes beweeg om sommige mense vir God te verkies. Die grond van ons uitverkiesing bly egter die liefdevolle, genade van God soos Bullinger dit oral leer (vgl. ook Bavinck 1928: Gereformeerde Dogmatiek 2.365-366).

- Die hele probleem van heilsekerheid ${ }^{18}$ wat dikwels hand aan hand gaan met die uitverkiesing soos dit in sommige formulerings van

18 Die denke van Beza raak evangeliese Christene vandag nog via die Westminster Confession of Faith en die 1689 Baptist Confession of Faith. Die sogenaamde "experimental predestinarianism" in Engeland is sterk deur hom beïnvloed en vind uiteindelik konfessionele neerslag in genoemde belydenisskrif (Kendall 1979). Soos die WCF (par.18.3) en die BCF (par.18.3 dit stel: "This infallible assurance does not so belong to the essence of faith, but that a true believer may wait long, and conflict with many difficulties, before he be partaker of it ..." 
Calvinisme neerslag gevind het (WCF \& BCF par.18.3), kan deur 'n herwaardering van Bullinger hokgeslaan word. Vanuit Bullinger se oogpunt kan daar vir gelowiges met vrymoedigheid gesê word dat hulle na Christus alleen kan kyk vir sekerheid. Hulle hoef nie te soek na enige iets agter Hom of buite Hom vir sekerheid nie. Dit kan geweldig bevrydend wees vir gelowiges wat vinger op die pols lewe voor God.

- 'n Vereenselwiging met Bullinger se denke kan ook help om isolasie en egotisme teen te staan. Die klem op die verband tussen soewereine, vrye uitverkiesing van God en verbond is 'n teëvoeter vir die gedagte dat ek as individu, of my Calvinistiese gemeente alleen uitverkore is as gevolg van enige beter verstaan vanaf ons kant. Christus en sy gemeente (kerk) wat baie baie wyer is as ek en my groepie is deur God verkies!

- Voortvloeiend hieruit is Bullinger se hantering van verbond en uitverkiesing 'n teëvoeter vir skolastiese logika en rasionalisme binne die evangeliese Christendom. 'n Neiging wat juis kan lei tot al die aanklagte teen die huidige beweging. Hy probeer nie die vraag beantwoord oor die rede waarom God die wêreld sou skep sonder om presies vooraf te dink wat Hy daarmee gaan doen nie. Het God nie van ewigheid af alles besluit soos dit gebeur nie? Bullinger weier om ja te antwoord. Hy weier om oor God te praat op 'n wyse wat tot misverstande kan lei oor sy goedheid en heiligheid. Hy weier om tot die gevolgtrekking te kom dat God die sonde op dieselfde wyse in sy raadsplan opgeneem het as die skepping of verlossing. Sy denke vorm dus nie 'n presiese, geslote logiese geheel nie, maar juis daarom is sy denke meer Bybels! Dit alleen lei ook weer tot groter nederigheid in die spreke oor God en sy werk - iets waarby huidige Nuwe Calviniste (New Calvinists) geweldig kan baat.

- Bullinger behandel nie uitverkiesing onder voorsienigheid, soos selfs die WCF nie. Sy denke en pastorale gerigtheid binne die raamwerk van die verbond kan baie help met die beantwoording van die tergende vrae omtrent God en lyding op so 'n wyse dat God nie as die harde, onbeweeglike eerste oorsaak van alle ellende gesien word nie. Die mens as bondgenoot wat in vryheid en met die gevolge daarvan optree, kan sonder spanning by die problematiek betrek word. 


\section{Slot}

Alhoewel Bullinger nie die verhouding tussen verbond en verkiesing breedvoerig in sy werke bespreek nie, het dit duidelik geword dat daar vanuit sy uitsprake wel gewaag kan word om tot sekere afleidings te kom waarby evangeliese Christene geweldig sal baat in die huidige situasie van verwarring.

$\mathrm{Na}$ afloop van hierdie studie kan daar daarom gewaag word om te sê dat 'n waardering en bestudering van Heinrich Bullinger se leer oor verbond en uitverkiesing die antwoord is op die verwarring en verdraaiings wat TULIP binne evangeliese teologie (evangelical theology) en die gestalte daarvan in die Nuwe Calvinisme (New Calvinism) beweging veroorsaak. Bullinger se leer aangaande die uitverkiesing en die verbond en die interaksie hiervan laat reg geskied aan die manier waarop die wat Bybel oor die wese van God en die wese van die mens praat. Bullinger se teologie hieromtrent maak dit moontlik om vanaf rasionalisme na Bybelse doksologie te beweeg.

Die volgende aanhaling uit Pine (1996:35) is 'n gepaste afsluiting vir hierdie artikel en onderstreep waarskynlik die logika agter die gebruik van Bullinger ook vir die tyd waarin ons onsself bevind:

Henry Bullinger died on September 17, 1575. His legacy of preaching, correspondence, books, doctrinal statements, and pastoral ministry had profound impact far beyond the limits of his sojourn on earth. Most remarkable was his tolerance of, and compassion for, others within the orthodox faith who differed from him in controversial points. His pastor's heart extended from his city's inhabitants to all of God's people. Theodore Beza rightly called Bullinger "the common shepherd of all Christian churches".

\section{Bronne}

Aucamp, C.A. 2011. "A comparative evaluation and theological analysis of the denominational practices of the Baptist Union of Southern Africa, SOLA 5 and the Fellowship of Baptist Churches in South Africa." PhD thesis, Faculty of Theology, North-West University, Potchefstroom. 
Bavinck, H. 1928. Gereformeerde Dogmatiek, III Vijfde onveranderd druk. Kampen: Kok.

Berkouwer, G.C. 1955. De Verkiezing Gods. Kampen: Kok.

Baker, J.W. 1980. Heinrich Bullinger and the Covenant: The other reformed tradition. Ohio: Ohio University Press.

Baker, J. 1998. "Heinrich Bullinger, the Covenant, and the Reformed Tradition in Retrospect". The Sixteenth Century Journal. 29:359-376.

Boetner, L. 1932. The reformed doctrine of Predestination. Arkansas: P\&R Publishing.

Bullinger, H. 1537. De Testamento seu Foedere Dei Unico et Aeterno, Commentarii H. Bullingeri in omnes Apostolicas epistolas. Basel: s.n.

Bullinger, H. 1545. De gratia Dei justificante nos propter Christum. Zürich: Christoffel Froschouer.

Bullinger, H. 1558. Seremones Ieremiae prophetae quattor, nempe secundas. Tertius, quartus \& quintus, comprehensiseptem capitibus, a VII. Videliced ad XIIII. Usque caput, XXVI. Heinrychi Bullingeri concionibus expositi. Zürich: Christophorus Froschouerus.

Bullinger, H. 1567. Isaias : excellentissimus Dei propheta, cuius testimoniis Christus ipse dominus et eius apostoli creberrime usi leguntur, expositus homiliis CXC, quibus non tam sensus prophetae redditur, quam usus \& fructus eius in Ecclesia Christi, ostenditur. Zürich: Christophorus Froschouerus.

Bullinger, H. 1849. The Decades. Cambridge: University Press.

Calvyn, J. 1984. Institusie van die Christelike godsdiens. Potchefstroom: Calvyn Jubileum Boekefonds.

Campi, E. 2004. Heinrich Bullinger und seine Zeit. Eine Vorlesungsreihe: Beiträge zur Geschichte Zwinglis der Reformation und des Protestantismus in der Schweiz. Zwingliana 31:110-133. Zürich: Zürcher \& Furrer.

Deist, F. 1992. A Concise Dictionary of Theological and Related Terms. Pretoria: JL van Schaik. 
Diedericks, M. 2014. Die voorsienigheidsleer van Calvyn: Uit sy debatte. Koers - Bulletin for Christian Scholarship. 79(4):1-9.

Diemer, N.S. 1935. Het scheppingsverbond met Adam: Het verbond der werken bij de theologen der 16e, 17e en 18e eeuw in Zwitserland, Duitscland, Nederland en Engeland, Dogmenhistorische studie. Kampen: Kok.

Doran, D.M. 2003. What Love is This? Detroit Baptist Seminary Journal. Fall:101-130.

Donnely, J.P. 1976. Calvinism and Scholasticism in Vermigli's Doctrine of Grace. Leiden: Leiden University Press.

Fahy, P. 2014. "New Calvinism is not like Calvin, in understanding ministries." [Intyds]. Beskikbaar: https://www.understanding-ministries.com [8 Oktober 2018]

Gordon, B. \& Campi, E. 2004. Architect of Reformation: An Introduction to Heinrich Bullinger, 1504-1575. Grand Rapids: Baker Academic.

Helm, P. 1994. "Calvin (and Zwingli) on divine providence". Calvin Theological Journal 29:388-405.

Hulse, E. 1993. Our Baptist heritage. Florida: Chapel Library.

Hodge, C. 1857. Systematic Theology III. Londen: Thomas Nelson.

Hunt, D. 2002. What love is this? New York: Loyal Publishing Co.

Jonker, W. 1989. Uit vrye guns alleen. Pretoria: NG-Kerkboekhandel.

Kendall, R.T.1979. Calvin and English Calvinism to 1649. Oxford: Oxford University Press.

Kickel, W. 1967. Vernuft und Offenbarung bei Theodore Beza. Neukirchen/ Vluyn: Neukirchener Verlag.

Kirby, T. 2005. "Heinrich Bullinger (1504-1575): Life - thought influence." Zwingliana. 32:107-117.

König, A. 1998. Evangelical Theology. In A. Maimela, \& A. König, (reds), InitiationiInto Theology. Pretoria: JL van Schaik. 81-110. 
Koning, J. \& Buys, P.J. 2016. "South African Reformed Baptists and contextualization: Contemp orary understanding, attitudes and praxis”. In die Skriflig (Intyds). 50:1-8

McCoy, C.S. \& Baker, J.W. 1991. Fountainhead of Federalism: Heinrich Bullinger and the covenantal tradition. Louisville: John Knox.

Merritt, J. 2014. “The troubling trends in America's 'Calvinist revival'”. In Religion News. [Intyds]. Beskikbaar: https://www.religionnews. com/2014/05/20/troubling-trends-americas-calvinist-revival/ [11 Maart 2018].

Mitchell, A.F. 1838. The Westminster assembly: Its history and standards. Londen: James Nisbet \& Co.

Mock, J. 2013. "Biblical and Theological Themes in Heinrich Bullinger's De Testamento (1534)”. Zwingliana. 40:1-35, Zürich: Zürcher \& Furrer.

Moltmann, J. 1961. Praedestination und perseveranz: Geschichte und bedeutung der reformierten Lehre „de perseverantia sanctoru“. Neukirchen: Neukirchener Verlag.

Muller, R.A. 2012. Calvin and the Reformed Tradition (E-book ed.). Grand Rapids:Baker Academic

Oliphint, J. 2014. "John Piper's twelve features of New Calvinism”. In Reformed Forum. [Intyds]. Beskikbaar: https://reformedforum.org/johnpipers-twelve-features-new-calvinism/ [8 Oktober 2018].

Opitz, P. 2004. Heinrich Bullinger als Theologe: Eine Studie zu den Dekaden. Zürich: Theologischer Verlag.

Oppenheimer, M. 2014. "Evangelicals find themselves in the midst of a Calvinist revival”. In Beliefs. [Intyds]. Beskikbaar: https://www.nytimes. com/2014/01/04/us/a-calvinist-revival-for-evangelicals.html [10 Maart 2017]

Pelikan, J. 1984. The Christian Tradition: A History of the Development of Doctrine, vol. 4. Chicago: University of Chicago Press.

Pine, L.W. 1996. "Heinrich Bullinger: The common shepherd of all churches.” WRS Journal. 3(2):30-35. 
Poythress, V. 1991. The shadow of Christ in the Law of Moses. Philipsburg, New Jersey: Presbyterian \& Reformed.

Rendtorff, R. 1998. The covenant formula: An exegetical and theological investigation. Edinburgh, Scotland: T\&T Clark.

Runia, K. 1997. "What is evangelical theology?" Evangelical Review of Theology. 21(4): 292-304.

Schweizer, A. 1854 Die protestantischen Centraldogmen in ihrer Entwicklung innerhalb der reformierten Kirche, Ist halb: Das 16. Jahrhundert. Zürich: Zürcher \& Furrer.

Sproul, R.C. 1997. What is reformed theology? Grand Rapids: Baker Books.

Steele, D., Thomas, C., Quin, L. 1963. The five points of Calvinism: Defined, Defended and Documented. Arkansas: P \& R Publishing.

Stewart, K.J. 2008, “The Points of Calvinism: Retrospect and Prospect.” Scottish Bulletin of Evangelical Theology. 26:187-203.

Torrance, J.B. 1994. “The concept of federal theology: Was Calvin a federal theologian?” In W.H. Neuser (ed.). Calvinus sacrae scriptura professor; Calvin as confessor of Holy, Scripture. Grand Rapids, MI: Eerdmans. 19-33.

Van Biema, D. 2009. “The new Calvinism.” Time Magazine. [Intyds]. Beskikbaar: http://content.time.com/time/specials/packages/artic le/0,28804,1884779_1884782_1884749,00.html [2 Maart 2017].

Van Bruggen, J. 1999. Matteus: Het evangelie voor Israël. Kampen: Kok.

Vance, L.M. 2002. "A review of Dave Hunts what love is this? Calvinism's misrepresentation of God." Journal of the Grace Evangelical Society. Autumn 2002:40-44.

Venema, C.P. 2005. "New Studies on Heinrich Bullinger." Zwingliana. 32:119-128.

Vos, G. 1980. "The Doctrine of the Covenant in Reformed Theology." In J. Gaffin (red.). Redemptive History and Biblical Interpretation: The Shorter Writings of Geerhardus Vos. Grand Rapids: Baker Book. 234-267. 
Wail, W.H. 1913. "The five points of Calvinism historically considered." The New Oulook 104.

Waldron, S.E. 1995. A modern exposition of the 1689 Baptist Confession of Faith. England: Evangelical Press.

Walser, P. 1957. Die predestination bei Heinrich Bullinger. Zürich: ZVZ.

Weber, H.E. 1951. Reformation, Ortodoxie und Rationalismus, BdII: Der Geist der Ortodoxie. Gütersloh: Bertelsmann.

Williamson, L.I. 1980. The Westminster Confession of Faith. Philadelphia: Presbeterian \& Reformed. 